\title{
Physicochemical Characterisation for Potential Uses as Industrial Mineral of Bauxite from Débélé, Guinea
}

\section{Mamadou Yaya Balde ${ }^{1,2}$, Chantale Njiomou Djangang ${ }^{*}$, Ramatoulaye Binta Diallo², Philippe Blanchart ${ }^{3}$, Daniel Njopwouo ${ }^{1}$}

\author{
${ }^{1}$ Department of Inorganic Chemistry, University of Yaounde I, Yaounde, Cameroon \\ ${ }^{2}$ Department of Chemistry, University Gamal Abdel Nasser of Conakry, Conakry, Guinea \\ ${ }^{3}$ Institute of Research for Ceramics-IRCER, Limoges, France \\ Email: *djangangc@yahoo.fr
}

How to cite this paper: Balde, M.Y., Djangang, C.N., Diallo, R.B., Blanchart, P. and Njopwouo, D. (2021) Physicochemical Characterisation for Potential Uses as Industrial Mineral of Bauxite from Débélé, Guinea. Journal of Materials Science and Chemical Engineering, 9, 9-22.

https://doi.org/10.4236/msce.2021.93002

Received: January 25, 2021

Accepted: March 19, 2021

Published: March 22, 2021

Copyright $\odot 2021$ by author(s) and Scientific Research Publishing Inc. This work is licensed under the Creative Commons Attribution International License (CC BY 4.0).

http://creativecommons.org/licenses/by/4.0/

\begin{abstract}
Assessing the potential uses as industrial mineral, bauxite from Débélé, Guinea, has been characterised by chemical and mineralogical analyses, the determination of the amorphous content, the rate of portlandite consumption in an aqueous solution, the strength activity index, and the thermal behaviour up to $1200^{\circ} \mathrm{C}$. It was evidenced that the raw sample is gibbsite-rich type bauxite with about $45.06 \mathrm{wt} \%$ of alumina, $23.80 \mathrm{wt} \%$ of iron oxide, and $1.74 \mathrm{wt} \%$ of silica. It meets the chemical composition required for bauxites used for refractory cement. During heating, the raw bauxite undergoes high densification with low linear shrinkage, motivating a potential use in dense ceramic compositions with high thermal stability. Also, the heating at only $600^{\circ} \mathrm{C}$ gives a significant pozzolanic activity in combination with Portland cement. The correlation between the pozzolanicity, the amorphous phase content, and the specific surface area indicated that the raw and the calcined materials present an interesting reactivity for using them in alternative cement formulations.
\end{abstract}

\section{Keywords}

Bauxite, Characteristics, Industrial Mineral, Guinea

\section{Introduction}

Bauxite is a source of diverse aluminum ores, with a high content of hydrated aluminum oxides such as gibbsite, boehmite, and diaspore. Apart from the metallurgical usage, bauxite has found diverse applications in manufacturing vari- 
ous products like cement, abrasives, refractories, chemicals, etc. Recently, bauxite has been used as an additive in various material compositions, to improve functional properties or for alternative sustainable products [1]-[6]. The industrial use of bauxite and derivatives materials is mostly based on the high aluminum hydroxide content, as gibbsite or boehmite. Gibbsite is mostly found in the clayed fraction of bauxite, as a secondary phase. It has many valuable effects on ceramic and cement applications due to the unique properties provided by alumina. As cementitious additives, gibbsite reacts with portlandite, having beneficial effects on cement hydration and paste rheology [4] [5] [7] [8] [9]. It was found that the replacement of Portland cement by gibbsite up to $12.5 \mathrm{wt} \%$ contributes to the significant reduction of the setting time of pastes, the two times increase of the mechanical strength, and the reduction of porosity. They are related to the high amount of ettringite crystals in the matrix that is favoured by the presence of gibbsite [5]. Besides, bauxite and bauxite derivatives have been used in valuable refractory ceramics, ceramic, and glass products. It is from the unique properties induced by the different forms of alumina obtained during the thermal process. They decrease the fluxing role of alkaline minerals, favouring the high mechanical resistance of products [10] [11] [12] [13] [14]. Beyond, bauxite found further application in water treatment, satisfactory elimination of certain toxic elements such as fluorides was obtained thanks to the improvement of adsorbent properties through the chemical and heat activation [6].

Recalling the sustainable approaches in different technological processes, they are also from the very large availability of raw material, and the related socio-economic development from local resources valorization. Guinean bauxite deposits are one of the world's main reserves that are used for metallurgical purposes by foreign companies [15] [16] [17] [18] [19]. The broader exploitation of this largely available resource is fundamental for socio-economic development, especially in the context of a developing country. The impact can be more effective if they are used in manufacturing building materials, electronics, and medical devices, or many more industrial and domestic products. This would enhance the development of local industries, with subsequent benefits like the creation of job opportunities, reduction in the cost of materials, and value-added welfares. The large scale of possible applications of this mineral resource is mostly based on the specific physicochemical characteristics. However, they are changing from one geographical site to another. It is essential to perform studies in potential uses according to the provenance. The present work aims to initiate investigations on bauxite quarried in Débélé site, Guinea, focusing on the chemical and structural compositions as well as on the thermal behaviour and the pozzolanic activity. It is a valuable contribution to the scientific database that can stimulate further development works.

\section{Methods}

\subsection{Studied Material Area}

The sample of bauxite used was quarried from the large deposit of Débélé lo- 
cated in Kindia Region of Guinea. It is the south-western part of the Bove Basin at $9^{\circ} 53^{\prime} \mathrm{N}-13^{\circ} 07 \mathrm{~W}$ (Figure 1). In comparison to previous geochemistry investigations carried out in this area, the sample is similar to a lateritic type that is formed in situ. It belongs to one of the two main types of bauxite that are associated with a sedimentary type founded in this area. The former type is characterised by its lower amount of alumina (30 - $60 \mathrm{wt} \%$ ) in comparison to that of other types (60 - $80 \mathrm{wt} \%)$ [18] [19].

\subsection{Material Sampling and Characterisation}

The as-received samples were dried at room temperature, crushed, and sieved below $75 \mu \mathrm{m}$, to obtain a powder with a red colour; $2.5 \mathrm{YR} 4 / 8$ according to the Munsel code [20]. The true density of the powder was measured with a helium pycnometer (micrometric model ACCUPYC 1330). The amorphous phase ( $A P)$ content was measured by vigorously stirring a mixture of $2 \mathrm{~g}$ of powder $\left(m_{i}\right)$ with $30 \mathrm{ml}$ of an $8 \mathrm{M}$ sodium hydroxide. The subsequent addition of $30 \mathrm{ml}$ of 0.5 $\mathrm{M}$ hydrochloric acid solution at $50^{\circ} \mathrm{C}$ for 5 minutes is followed by washing with distilled water and centrifugation, to obtain a neutral $\mathrm{pH}$ residue that was dried at $110^{\circ} \mathrm{C}$ until a constant mass $\left(m_{f}\right)$. The amorphous content is given by Equation (1) [12].

$$
A P(\%)=\frac{m_{i}-m_{f}}{m_{f}} \times 100
$$

The specific surface area (SSA) of the cement powder was measured by $\mathrm{N}_{2}$ adsorption in BET [21]. The chemical composition was obtained by X-ray fluorescence spectrometry (XRF) using a Bruker S8 apparatus and the mineralogical composition was obtained by X-ray powder diffraction (XRD) with the grounded sample below $40 \mu \mathrm{m}$, using a Bruker D8 Advance diffractometer (copper anode: $\lambda=1.5418 \AA$; graphite monochromator; step size of $0.01^{\circ} 2 \theta, 0.1$ s per step). Crystalline phases were identified by comparing the models with the standards of the powder diffraction files. This analysis was completed by infrared spectroscopy (FTIR) using a Bruker spectrometer in the absorbance mode between wavenumbers of 4000 and $400 \mathrm{~cm}^{-1}$. Samples were obtained by the $\mathrm{KBr}$ cap method. Thermal analyses, DTA (Differential thermal analysis) and TGA (Thermogravimetric analysis) were performed with a TA instrument Q600 SDT under a flow rate of dry air $(100 \mathrm{ml} / \mathrm{min})$. The semi-quantitative mineralogical compositions of samples were calculated using the method developed by Njopwouo (1984) and Yvon et al. (1990) [22] [23]. Calculated data were correlated with thermal and chemical results, and with XRD analyses. The sintering behaviour was characterized up to $1200^{\circ} \mathrm{C}$ with a DI 24 ADAMEL dilatometer with a heating rate of $5^{\circ} \mathrm{C} / \mathrm{min}$.

The pozzolanicity degree was obtained considering the consumption of calcium hydroxide $(\mathrm{CH})$ in an aqueous solution, by the Modified Chapelle Method [9]. The determination of the amorphous phase quantity and the Modified Chapelle Method was carried out simultaneously with both the raw sample and the 


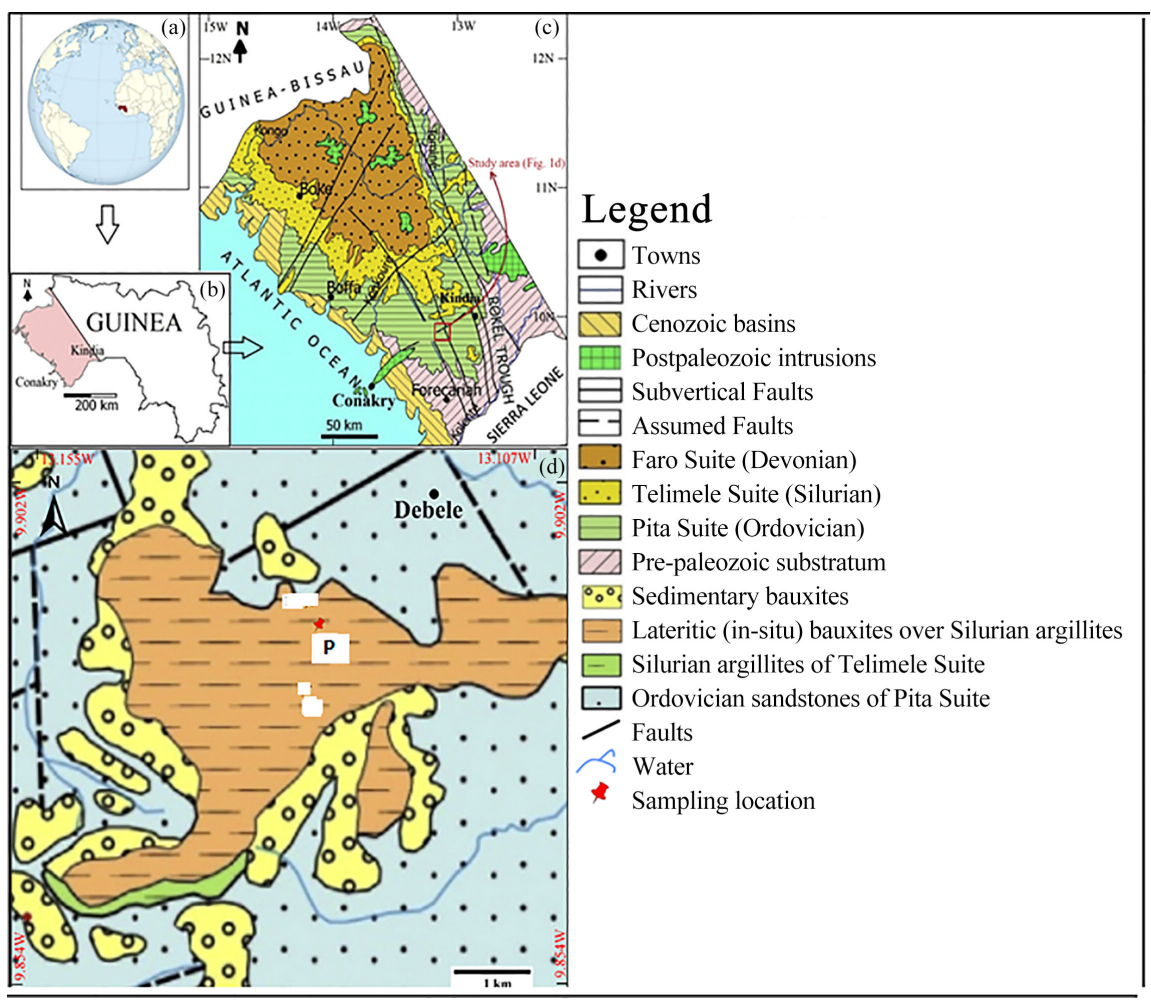

Figure 1. Study area location: (a) Guinea's location in the world; (b) Kindia and Conakry with Maritime Guinea and its location in Guinea; (c) Geological map of the study area showing Balaya plateaus and its surrounding area and (d) Sampling location in the local geology [18] [19].

calcined product at $600^{\circ} \mathrm{C}$, inside a muffle furnace (heating rate of $5^{\circ} \mathrm{C} / \mathrm{min}$ ). To complain about the ASTM C618 standard, the chemical composition was considered in results since the limiting value of mass percentages of $\mathrm{Al}_{2} \mathrm{O}_{3}+\mathrm{SiO}_{2}+$ $\mathrm{Fe}_{2} \mathrm{O}_{3}$ must be $70 \mathrm{wt} \%$ for pozzolanic material. The strength activity index (I), which is also the quantification of pozzolanicity, was measured according to ASTM C109 and C618-94 [24] [25]. Specific, mortars were obtained by mixing $1 / 3$ of the binder with $2 / 3$ of the sand and with water, as indicated in the EN F 196-1 Standard [26].

Mechanical characterisations were obtained with cubic test samples $(4 \times 4 \times 4$ $\mathrm{cm})$. They were shaped from fresh mortars that were poured into metallic moulds. The compaction was improved by vibrations during $10 \mathrm{~min}$ (electrical vibrating table; $\mathrm{M} \& \mathrm{O}$. type $202, \mathrm{~N}^{\circ} 106$ ) to remove entrapped air bubbles. The setting was under plastic films in a controlled air atmosphere (HR $\left.100 \% ; 20^{\circ} \mathrm{C}\right)$. After 28 days of setting, the compressive strengths $(R c)$ of test samples were measured by NF P18-406 [27], using a hydraulic press (LMC type C004, No. 89/54800). The peak strength values were obtained considering a polynomial correction method that is:

$$
F(\text { in } \mathrm{KN})=1.02 \times X \pm 0.24
$$

where $X$ is the read value $(\mathrm{KN})$.

The compressive strength $R c(\mathrm{MPa})$ is given by Equation (2): 


$$
R C=\frac{F}{S}
$$

where $F$ is the breaking strength $(\mathrm{N})$ and $S$ is the cross-section of the specimen in $\mathrm{mm}^{2}$.

The strength activity index ( $I)$ was calculated using Equation (3):

$$
I=100 \times \frac{R c_{28 j}(H M)}{R c_{28 j}(C M)}
$$

where $R c_{28}(H M)$ is the compressive strength after setting of a hybrid mortar where $20 \%$ wt $\%$ of Portland cement is replaced by the bauxite powder. $R c_{28 j}(C M)$ is the compressive strength of the reference mortar containing $100 \%$ of Portland Cement.

\section{Results and Discussion}

\subsection{Physical Characteristics}

From Table 1 presenting some physical parameters of the bauxite sample, the absolute density of the powder is $2.66 \mathrm{~g} \cdot \mathrm{cm}^{-3}$, which is slightly higher than that of gibbsite $\left(2.42 \mathrm{~g} \cdot \mathrm{cm}^{-3}\right)$. This value outlines the high degree of compaction at the crude state since it is an important intrinsic parameter of the material at the specific granulometry. It is therefore useful for monitoring and understanding the performance when shaping products based on the studied material [28].

The amount of amorphous phase in the raw bauxite is $30.8 \%$, and it raises $51.2 \%$ after calcination at $600^{\circ} \mathrm{C}$. The significant increase of amorphous phase content with heating is related to a reactivity improvement since phases react easily with others in mixtures due to higher free energy in comparison to that of the crystallised phases. The amorphous content is therefore a leading factor for the use of a material as a mineral additive in the cementitious matrix or for the formulation of alternative cements such as geopolymers [29] [30]. As for the pozzolanic degree, the bauxite powder sample exhibit a value of $748 \mathrm{mg}$ of $\mathrm{CH}$ fixed per gram of sample, which is close to the lower limiting value of $700 \mathrm{mg}$ reported in the ASTM C618-94 standard for pozzolanic material. Correspondingly, the calcined sample (CB) presents a very high value of $999.9 \mathrm{mg}$ of $\mathrm{CH}$ fixed per gram of sample. The same trend can be observed with the mechanical activity index which is $71 \%$, and this value is similar to that from most of the cementitious materials reported in the literature [9] [31] [32].

Table 1. Physicochemical characteristics.

\begin{tabular}{ccc}
\hline Parameters & Raw $(\mathrm{RB})$ & Calcined (CB) \\
\hline Absolute density $\left(\mathrm{g} \cdot \mathrm{cm}^{-3}\right)$ & 2.66 & - \\
Specific surface area: SSA $\left(\mathrm{m}^{2} \cdot \mathrm{g}^{-1}\right)$ & 3.60 & 4.32 \\
Amorphous phase $(\%)$ & 30.8 & 51.2 \\
Mass of CH* $(\mathrm{mg})$ fixed & 748 & 999.9 \\
Activity index: I (\%) & 71 & 72.7 \\
\hline
\end{tabular}

* $\mathrm{CH}$ is from the Modified Chapelle Method. 


\subsection{Chemical Composition and Structural Characteristics}

The chemical composition of the studied sample (Table 2) showed the predominance of alumina $\mathrm{Al}_{2} \mathrm{O}_{3}$ (46.06 wt\%), the presence of iron oxide $\mathrm{Fe}_{2} \mathrm{O}_{3}(23.80$ $w t \%)$, and small amounts of silica $\mathrm{SiO}_{2}(1.74 \mathrm{wt} \%)$ and titanium oxide $\mathrm{TiO}_{2}(1.74$ $\mathrm{wt} \%)$. The loss of ignition is $25.60 \mathrm{wt} \%$. It is a typical composition of lateritic bauxite, as it was reported by published studies about that geographical area [20] [21] [33]. This composition is similar to that of bauxites used for refractory cement since the compositional range is 45 to $60 \mathrm{wt} \%$ of alumina; up to $25 \mathrm{wt} \%$ of iron oxide; below $5 \mathrm{wt} \%$ of silica [34]. From the XRD pattern (Figure 2), gibbsite was identified as the major phase, the other minerals are hematite, quartz, and anatase. Gibbsite is then the only mineral containing aluminum oxide, accordingly, from the proportion of the latter obtained by XRF, that of gibbsite was evaluated to $70.5 \mathrm{wt} \%$. Also, the DTA and TG analyses in Figure 3 show a large endothermic peak and a weight loss at $311^{\circ} \mathrm{C}$. It is related to the partial dehydroxylation of gibbsite giving boehmite (Equation (4)). At $380^{\circ} \mathrm{C}$, an embedded small peak is also ascribed to gibbsite transformation into boehmite that often occurs in the range of $300^{\circ} \mathrm{C}-310^{\circ} \mathrm{C}$. However, the temperature range can be shifted to $350^{\circ} \mathrm{C}-380^{\circ} \mathrm{C}$ with well-crystallised gibbsite. The phase transformation is written in Equation (4):

Table 2. Chemical and mineralogical composition of the studied bauxite.

\begin{tabular}{|c|c|}
\hline \multicolumn{2}{|c|}{ Chemical composition } \\
\hline $\mathrm{Al}_{2} \mathrm{O}_{3}$ & 46.06 \\
\hline $\mathrm{Fe}_{2} \mathrm{O}_{3}$ & 23.80 \\
\hline $\mathrm{SiO}_{2}$ & 1.74 \\
\hline $\mathrm{TiO}_{2}$ & 1.74 \\
\hline $\mathrm{CaO}$ & 0.06 \\
\hline $\mathrm{P}_{2} \mathrm{O}_{5}$ & 0.06 \\
\hline $\mathrm{Cr}_{2} \mathrm{O}_{3}$ & 0.18 \\
\hline $\mathrm{SO}_{3}$ & 0.09 \\
\hline $\mathrm{MgO}$ & $<0.01$ \\
\hline $\mathrm{Na}_{2} \mathrm{O}$ & $<0.01$ \\
\hline $\mathrm{K}_{2} \mathrm{O}$ & $<0.01$ \\
\hline LOI & 25.6 \\
\hline Total & 99.36 \\
\hline \multicolumn{2}{|c|}{ Mineralogical composition } \\
\hline Gibbsite & 69.50 \\
\hline Hematite & 23.80 \\
\hline Quartz & 1.74 \\
\hline Anatase & 1.74 \\
\hline Total & 96.78 \\
\hline
\end{tabular}




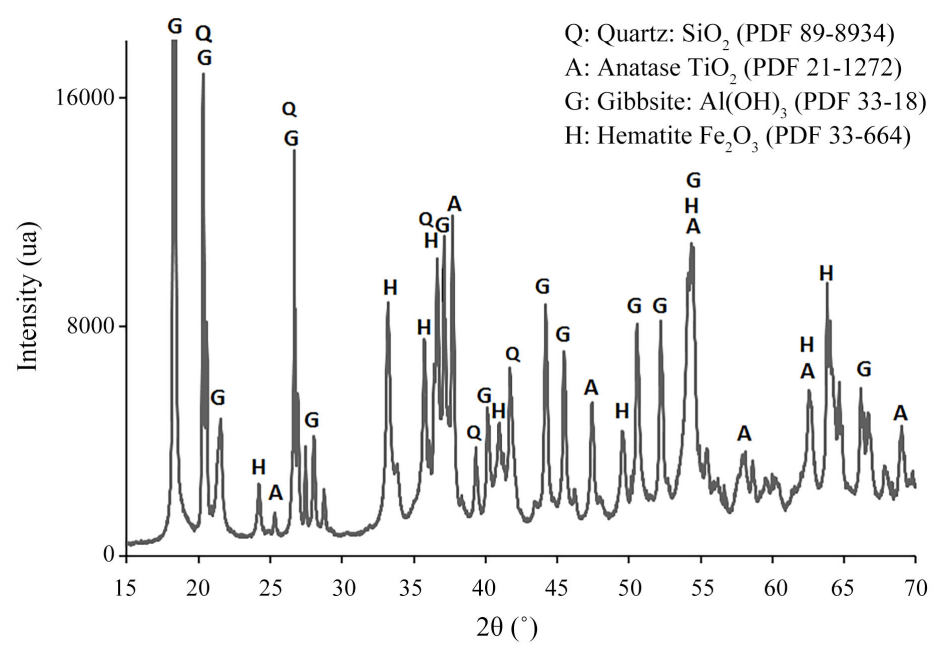

Figure 2. Diffractogram of the bauxite sample.

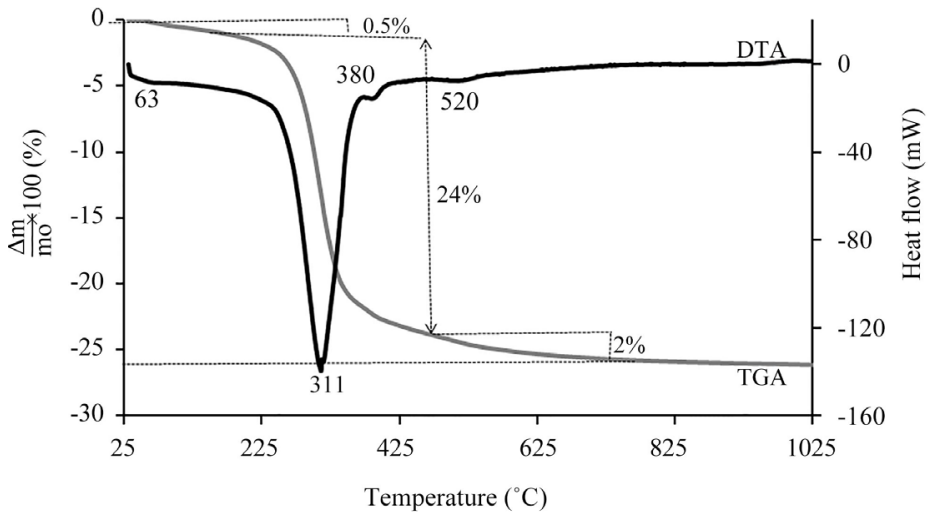

Figure 3. DTA/TGA curve of the bauxite sample.

$$
\mathrm{Al}(\mathrm{OH})_{3} \rightarrow \mathrm{AlO}(\mathrm{OH})+\mathrm{H}_{2} \mathrm{O}
$$

At higher temperatures, a less pronounced endothermic peak is at $520^{\circ} \mathrm{C}$. It corresponds to the conversion of boehmite into $\gamma$-alumina (Equation (5)) [35] [36] [37] [38]:

$$
2 \mathrm{AlO}(\mathrm{OH}) \rightarrow \gamma-\mathrm{Al}_{2} \mathrm{O}_{3}+\mathrm{H}_{2} \mathrm{O}
$$

The total weight loss for the whole process is $24 \mathrm{wt} \%$, and since gibbsite is the only mineral that undergoes mass loss as state above in relation to the departure of $\mathrm{OH}$ groups, the total gibbsite content is calculated to $69.5 \mathrm{wt} \%$. Finally, a semi-quantitative composition can be obtained from information provided by the chemical, thermal, and XRD analyses. It gives $69.50 \mathrm{wt} \%$ of gibbsite, 23.80 wt $\%$ of hematite, $1.74 \mathrm{wt} \%$ of quartz, and $1.74 \mathrm{wt} \%$ of anatase. Gibbsite quantity obtained (70.5\%) from XRF data (Table 2) is very close to that obtained from the TGA curve (Figure 3) 69.5\%, with a deviation of $1 \%$, reflecting very good correlation between the two methods. This compositional range indicates that the studied bauxite is a class 2 bauxite containing less than $80 \mathrm{wt} \%$ of gibbsite and more than $20 \mathrm{wt} \%$ hematite [1] [3].

Observations on the structural characteristics of the studied bauxite agree with 
FTIR analyses presented in Figure 4 . The behaviour of the raw bauxite is compared to that of the heat-treated material at $600^{\circ} \mathrm{C}$. In Figure 4 the raw bauxite exhibited absorption bands grouped in three regions: at 3619, 3525, 3445, 3375 $\mathrm{cm}^{-1}$; at 1020 and $960 \mathrm{~cm}^{-1}$; at 800,750 , and $550 \mathrm{~cm}^{-1}$, they are all related to the stretching of hydroxyl groups (Al-OH) in gibbsite [1] [33] [39] [40]. The heat-treated sample (Figure 4) evidence that these bands have disappeared with the thermal treatment since the $\mathrm{OH}$ groups are not more after the departure of structural water. The remaining absorption bands are at 500, 470, and $447 \mathrm{~cm}^{-1}$ for $\mathrm{Si}-\mathrm{O}$ and $\mathrm{Si}-\mathrm{O}-\mathrm{Si}$ of quartz as well as for $\mathrm{Fe}-\mathrm{O}$ of hematite.

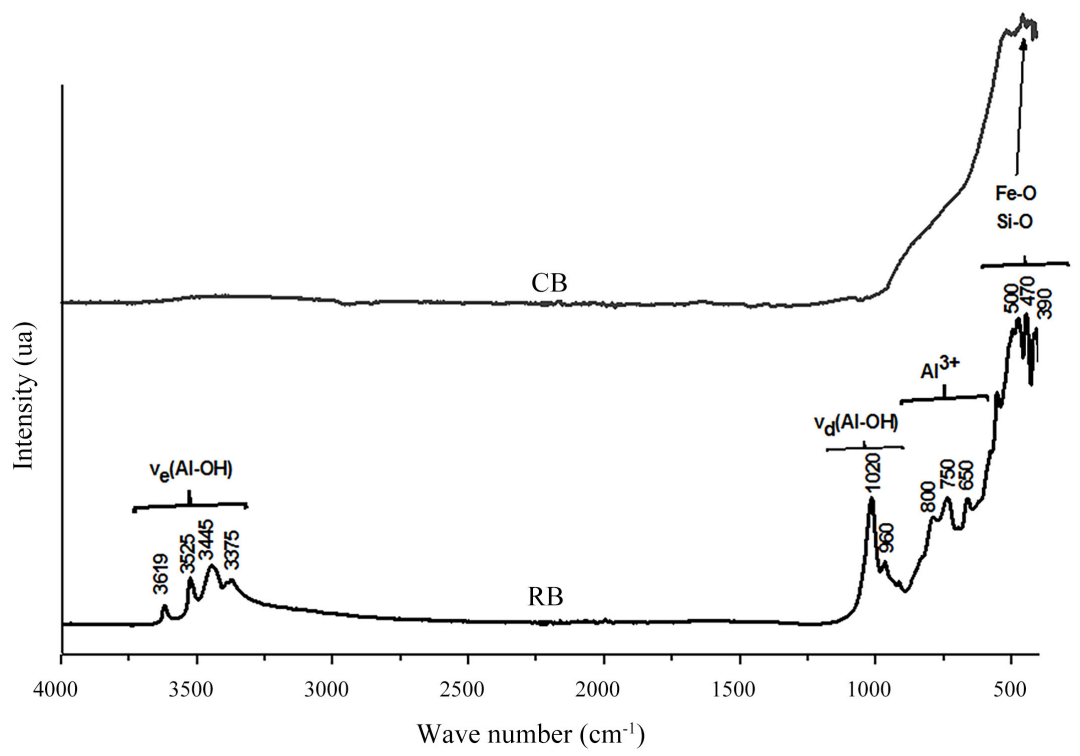

Figure 4. Infrared Spectrum of RB: raw bauxite and CB: calcined bauxite.

\subsection{Sintering Behavior}

The densification with a temperature of the bauxite sample, up to $1200^{\circ} \mathrm{C}$ as well as the densification rates plotted against time and temperature are presented in Figure 5 and Figure 6.

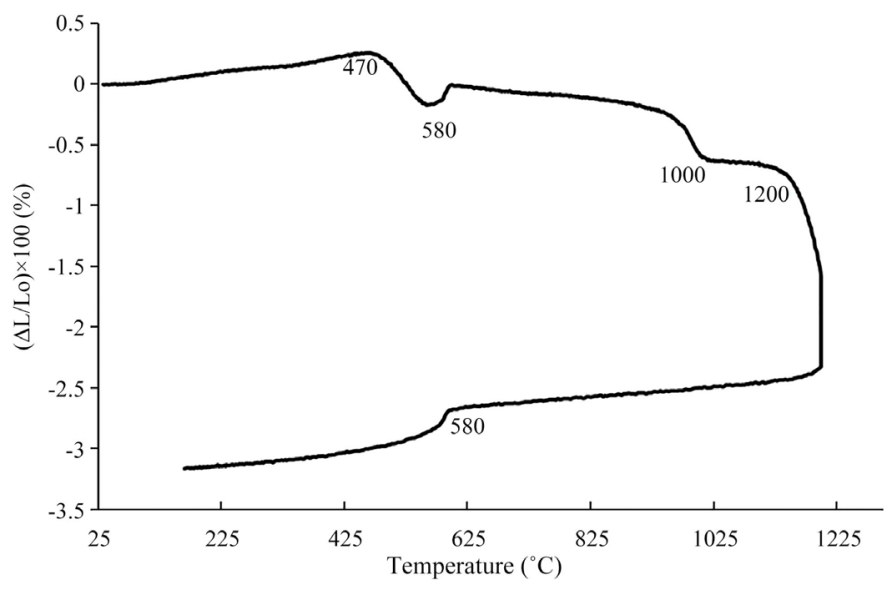

Figure 5. Dilatometric curve of the bauxite sample. 


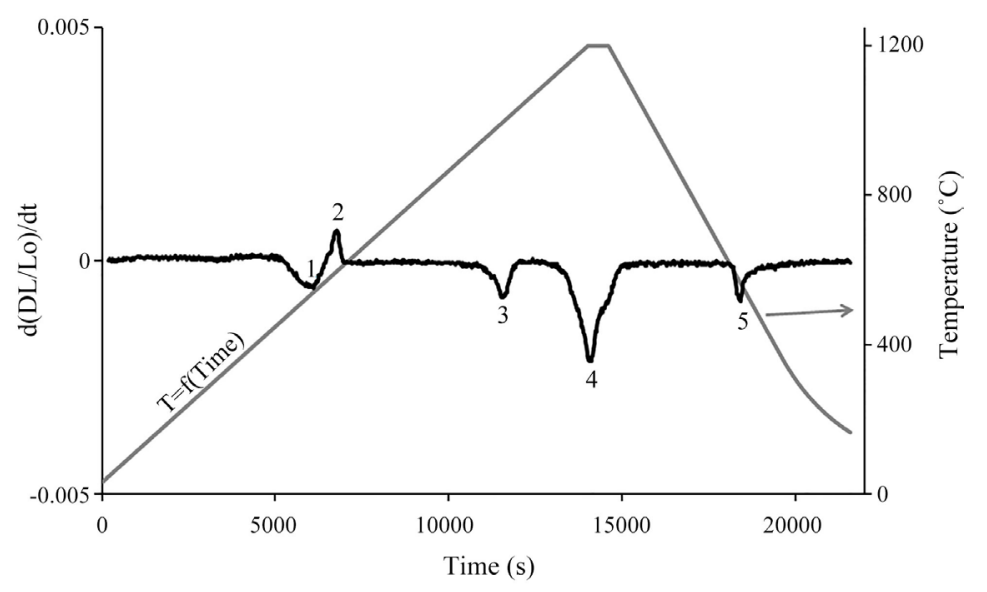

Figure 6. Densification curve of the bauxite sample.

From the ambient temperature, there is a progressive dilatation up to $470^{\circ} \mathrm{C}$, which is probably related to the activation of the system with heating. A consecutive shrinkage begins at $430^{\circ} \mathrm{C}$, about the dehydroxylation of the gibbsite, which is accompanied by a peak of the densification rate at $530^{\circ} \mathrm{C}$. A small variation of the dilatation is at $573^{\circ} \mathrm{C}$, corresponding to the volume expansion of quartz grains during the polymorphic transformation of quartz $\alpha \rightarrow \beta$; it is a reversible phenomenon since during cooling a volume reduction is seen at the same temperature. From $600^{\circ} \mathrm{C}$ to $977^{\circ} \mathrm{C}$, densification occurs and becomes more accentuated (volume reduction of about 1 vol \%) below $977^{\circ} \mathrm{C}$. It is related to the departure of structural hydroxyl in boehmite with the formation of gamma-alumina $\left(\gamma-\mathrm{Al}_{2} \mathrm{O}_{3}\right)$. Above $1000^{\circ} \mathrm{C}$, the accentuated shrinkage is correlated with a peak at $1190^{\circ} \mathrm{C}$ in the thermal expansion rate curve. It is more likely related to the progressive transformation of aluminum hydroxide into transitional alumina phases, as $\gamma$ or $\kappa$ alumina, and finely $\alpha$ alumina, increasing the crystallinity degree of phases [3] [40] [41]. The overall thermal transformation of the bauxite sample at $1200^{\circ} \mathrm{C}$, lead to a total linear shrinkage of $3.2 \%$. This relatively low value indicates that the studied bauxite is suitable in manufacturing dense ceramics, for specific applications requiring dimensional stability [12] [42].

\subsection{Discussion}

The investigations on the physicochemical characteristics of the bauxite sample from Débélé evidence that the material is mostly composed of gibbsite. It is a well-known crystallized aluminum hydroxide mineral that is used in different industrials sectors and mostly in the manufacture of refractory materials. It is preferable to the other hydrated aluminum oxides because it readily dissolves to available alumina at low temperatures and pressures [41] [43]. In general bauxite exhibits interesting thermal behaviour and low firing shrinkage, which does not exceed $3.2 \%$ at $1200^{\circ} \mathrm{C}$ for the studied sample. Consequently, bauxite can be used for manufacturing dense ceramics having enhanced dimensional stability [42]. Besides, some of the properties of the studied sample are supposed to be beneficial in different sectors as for cementitious and geopolymer additives. 
When bauxite is heat-treated at $600^{\circ} \mathrm{C}$ some of the properties are significantly improved. It is evidenced in Figure 7, presenting the effect of temperature on different properties: the variation of the amorphous phase content (AP). The amount of the amorphous phase increases from $30.8 \%$ for the crude sample to $51.2 \%$ for the calcined sample at $600^{\circ} \mathrm{C}$; the strength activity index (I) and the capacity to fix portlandite $(\mathrm{m}(\mathrm{CH}))$; the increase of the specific surface SSA.

The amorphous phase is the most active in the pozzolanic activity, and its quantity is a key characteristic of the material together with the specific surface area and the chemical composition. This promoting role is controlled by the relatively high free energy that exceeds that of the crystalline phase. Amorphous species are chemically more reactive with the surrounding particles. The increase of the content of the amount of amorphous phase is well correlated with the pozzolanic activity since it is the ability to fix portlandite in the presence of water ASTM C125-07 [44]. Reactivity processes are also related to the increase of SSA. From Figure 7, it increases with the calcination temperature from 3.60 to $4.32 \mathrm{~m}^{2} \cdot \mathrm{g}^{-1}$.

The interaction of portlandite with alumina is expected to be the dominant chemical reaction that is followed by the interaction of different oxides. They are mostly silica and iron oxide, considering the chemical composition of the studied bauxite (Table 2). Correspondingly, the mass of $\mathrm{CH}$ fixed per gram of sample has increased with the temperature, from the limiting value of $748 \mathrm{mg}$ to a higher value of $999.9 \mathrm{mg}$. It is significantly higher than that obtained with other pozzolanic materials, and particularly with metakaolin [9] [45]. The amount of newly formed compounds raises, as aluminates or pozzolanic compounds that favour the increase of the mechanical strength of materials.
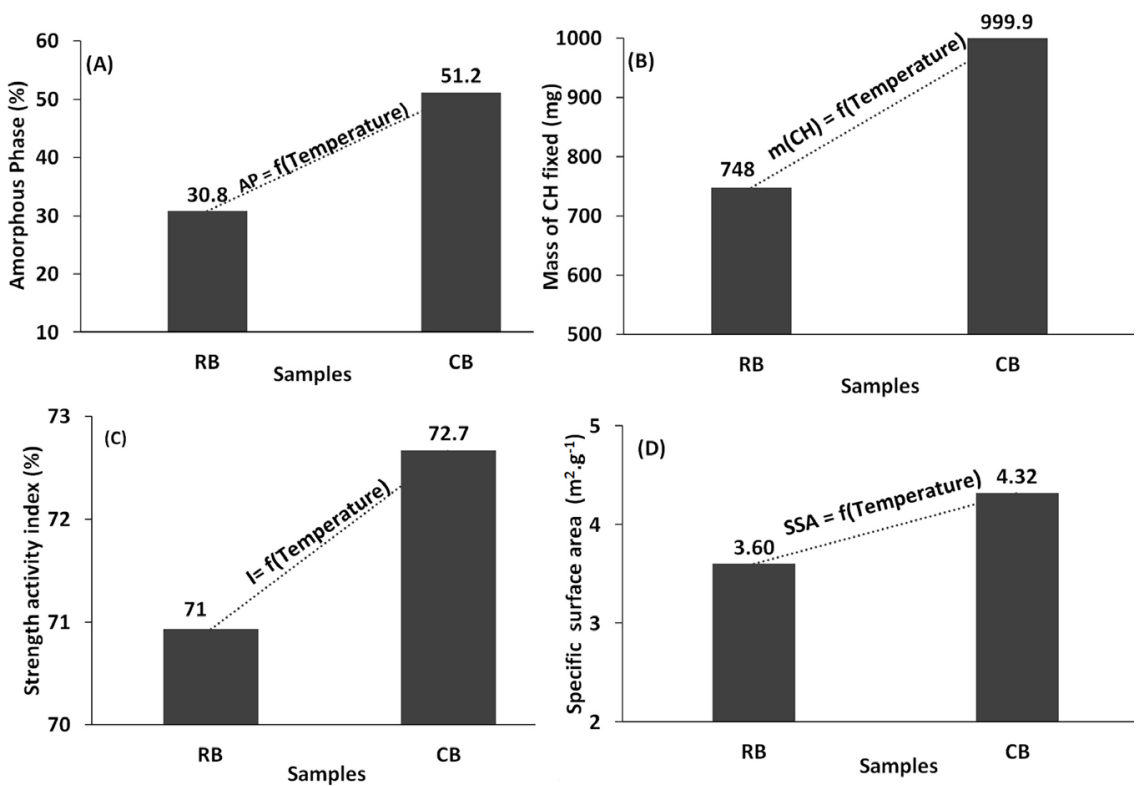

Figure 7. Effect of temperature on the physicochemical parameters of bauxite: AP: amorphous phases; $\mathrm{CH}$ : portlandite; I: strength activity index; SSA: specific surface area; RB: raw bauxite; $\mathrm{CB}$ : calcined bauxite. 
Finally, it is evidenced that the studied bauxite sample has a significant pozzolanic activity that can be further improved with heat treatment. Bauxite is an interesting material for partially replacing Portland cement in the mixture of concretes. It can be used also in geopolymer formulations that require reactive aluminosilicate species.

\section{Conclusion}

The characterisations of bauxite from Débélé show the presence of mostly alumina hydroxide, but also iron oxide, and silica and titanium oxide are in small quantities. The chemical composition is similar to those of mined bauxites already used in alumina cement and concretes. The sample contains mostly the gibbsite mineral that is an efficient component for the improvement of refractory ceramics since it forms in-situ reactive alumina. The determination of both the amorphous phase content, of the rate of portlandite consumption in an aqueous media, and the strength activity index evidence the high pozzolanic activity. The amorphous phase content can be easily increased by a heat treatment at a relatively low temperature of $600^{\circ} \mathrm{C}$. It is an interesting way to improve the behaviour of hydraulic binders as Portland and geopolymers cement. Besides, the properties of refractory ceramics are also improved since the high densification during firing at $1200^{\circ} \mathrm{C}$ occurs with low linear shrinkage. It is favourable to the production of net-shape refractory ceramics even in the case of large-sized pieces.

\section{Acknowledgements}

The authors acknowledge the financial assistance from the Government of Guinea under the National Training Programme for Trainers, the University of Yaoundé I, Cameroon, for making analyse facilities available thankful to its partnership with the Institute of Research for Ceramics - IRCER, France and to the support of TWAS, RG / 19-206 RG/CHE/AF/AC_G /4500411470.

\section{Conflicts of Interest}

The authors declare no conflicts of interest regarding the publication of this paper.

\section{References}

[1] Tchamba, A.B., Yongue, R., Melo, U.C., Kamseu, E. and Njoya, D. (2008) Caractérisation de la bauxite de Haléo-Danielle (Minim-Martap, Cameroun) en vue de son utilisation industrielle dans les matériaux à haute teneur en alumine. Silicates industriels, 73, 77-84.

[2] Tchamba, A.B., Melo, U.C., Kamseu, E., Yongue, R. and Njopwouo, D. (2010) Comportement thermique et de frittage des bauxites d'Haleo-Danielle, MinimMartap (Cameroun). Céramique industrielle, 30, 21-26.

[3] Tchamba, A.B., Melo, U.C., Yongue, R. and Njopwouo, D. (2011) Phase and Microstructure Evolution during Densification of Bauxite of Haleo-Danielle (MinimMartap, Cameroon) between 1000 and 1600 C. International Journal of Materials 
Science, 6, 89-100.

[4] Ribeiro, D.V., Labrincha, J.A. and Morelli, M.R. (2011) Potential Use of Natural Red Mud as Pozzolan for Portland Cement. Materials Research, 14, 60-66. https://doi.org/10.1590/S1516-14392011005000001

[5] Dai, Y.S., Tan, Y.H., Wu, J.H., Wang, Y. and Lu, C.H. (2016) Propriétés du mortier de coulis modifié à la bauxite minérale par activation chimique. Journal of Materials in Civil Engineering, 28, Article ID: 04016057. https://doi.org/10.1061/(ASCE)MT.1943-5533.0001562

[6] Haddad, A.Z., Pilgrim, C.D., Sawvel, A.M., Hohman, J.N. and Gadgil, A.J. (2019) On the Conversion of Bauxite Ores to Highly Activated Alumina Media for Water Remediation. Advanced Sustainable Systems, 3, Article ID: 1900005. https://doi.org/10.1002/adsu.201900005

[7] Ribeiro, D.V., Silva, A.S., Labrincha, J.A. and Morelli, M.R. (2013) Rheological Properties and Hydration Behavior of Portland Cement Mortars Containing Calcined Red Mud. Canadian Journal of Civil Engineering, 40, 557-566. https://doi.org/10.1139/cjce-2012-0230

[8] Danner, T. and Justnes, H. (2020) Bauxite Residue as Supplementary Cementitious Material-Efforts to Reduce the Amount of Soluble Sodium. Nordic Concrete Research, 62, 1-20. https://doi.org/10.2478/ncr-2020-0001

[9] Tchamo, L.C.C., Libessart, L., Djelal, C., Djangang, N.C. and Elimbi, A. (2020) Pozzolanic Activity of Kaolinitic Clays with Aluminum Hydroxide Used for Cement Mortar. Scientific Rapports, 10, 1-12. https://doi.org/10.1038/s41598-020-70146-3

[10] Yalçin, N. and Sevinç, V. (2000) Utilization of Bauxite Waste in Ceramic Glazes. Ceramics International, 26, 485-493. https://doi.org/10.1016/S0272-8842(99)00083-8

[11] Poirier, J. (2011) Les céramiques réfractaires de l'élaboration aux propriétés d'emploi. Verres Céramiques and Composites, 1, 28-42.

[12] Djangang, N.C., Kamseu, E., Tchamo, C.C., Capsoni, D., Elimbi, A. and Njopwouo, D. (2015) Sustainable Binders from High Amount of Gibbsite Associate with Kaolinitic Clay. Annales de Chimie Science des Matériaux, 39, 75-91. https://doi.org/10.3166/acsm.39.75-92

[13] Verma, A.S., Suri, N.M. and Kant, S. (2017) Applications des résidus de bauxite: Une mini-revue. Waste Management and Research, 35, 999-1012. https://doi.org/10.1177/0734242X17720290

[14] Tchamba, A.B., Mbessa, M., Jordan, V.J. and Metekong, S. (2019) Mechanical and Microstructural Properties of Cameroonian Bauxite Ceramics for Ballistic Applications. International Journal of Applied Ceramic Technology, 17, 949-962. https://doi.org/10.1111/ijac.13383

[15] Campbell, B. (1993) Le secteur de la bauxite en République de Guinée: Ajustement structurel et restructuration internationale de l'industrie de l'aluminium. Tiers-Monde, 34, 187-208. https://doi.org/10.3406/tiers.1993.4833

[16] Boulvert, Y. (2003) La Guinée: Atouts et handicaps au seuil du troisième millénaire. Géographie-Paris-Société de Géographie, 55-75.

[17] Devey, M. (2009) La Guinée. KARTHALA Editions 2009.

[18] Mamedov, V.I., Bouféév, Y.V. and Nikitine, Y.A. (2010) Géologie de la République de Guinée. Volume I, Géoprospects Ltd., Moscou.

[19] Sidibé, M. and Yalcin, M.G. (2019) Petrography, Mineralogy, Geochemistry and Genesis of the Balaya Bauxite Deposits in Kindia Region, Maritime Guinea, West Africa. Journal of African Earth Sciences, 149, 348-366. 
https://doi.org/10.1016/j.jafrearsci.2018.08.017

[20] Cailleux, A. (1975) Munsell Soil Color Charts: Quoted in Part from the U.S. Dept. Agriculture Handbook, 18-Soil Survey Manual, Baltimore Maryland Boubée.

[21] Atheba, P., Gbassi, G.K., Dongui, B., Bamba, D., Yolou, F.S. and Trokourey, A. (2014) Studies of Porosity, Specific Surface Area and Surface Functions of Activated Carbons Prepared after Traditional Carbonization of Coconut Shells. Les technologies de laboratoire, 8, 126-136.

[22] Njopwouo, D. (1984) Minéralogie et physico-chimie des argiles de Bomkoul et de Balengou (Cameroun) Utilisation dans la polymérisation du styrène et dans le renforcement du caoutchouc naturel. Thèse $\mathrm{PhD}$, Université de Yaoundé $\mathrm{I}$.

[23] Yvon, J., Baudracco, J., Cases, J.M. and Weiss, J. (1990) Éléments de minéralogie quantitative en micro-analyse des argiles. Matériaux Argileux, Structures, Propriétés et Applications, 473-489.

[24] ASTM C109 (2008) Méthode d'essai pour la résistance à la compression des mortiers de ciment hydrauliques. ASTM International, West Conshohocken.

[25] ASTM C618-08 (2008) Standard Specification for Coal Fly Ash and Raw or Calcined Natural Pozzolan for Use in Concrete. Annual Book of ASTM Standards, West Conshohocken.

[26] NF EN 196-1 (2006) Méthodes d'essais des ciments-Partie 1: Determination des résistances mécaniques. Methods of Testing Cements Part 1: Determination of Mechanical Strengths.

[27] NF P 18-406 AFNOR (1990) Béton-Essai de compression.

[28] Callister, W.D.J. (1994) Materials Science and Engineering: An Introduction. Third Edition, John Wiley and Sons, Inc., New York.

[29] Diaz, E.I., Allouche, E.N. and Eklund, S. (2010) Factors Affecting the Suitability of Fly Ash as Source Material for Geopolymers. Fuel, 89, 992-996.

https://doi.org/10.1016/j.fuel.2009.09.012

[30] Poudeu, R.C., Ekani, C.J., Djangang, N.C. and Blanchart, P. (2019) Role of Heat-Treated Laterite on the Strening of Geopolymer Designed with Laterite as Solid Precursor. Annales de Chimie Science des Matériaux, 43, 359-367. https://doi.org/10.18280/acsm.430601

[31] Walker, R. and Pavia, S. (2011) Physical Properties and Reactivity of Pozzolans, and Their Influence on the Properties of Lime-Pozzolan Pastes. Materials and Structures, 44, 1139-1150. https://doi.org/10.1617/s11527-010-9689-2

[32] Savadogo, N., Messan, A., Hannawi, K., Tsobnang, F. and Agbodjan, W.P. (2015) Durabilité d'un ciment composé à base de mâchefer de Tefereyre (Niger): Absorption capillaire, porosité accessible à l'eau et attaque acide. Journal of Materials and Engineering Structures, 2, 213-223.

[33] Njoya, D., Njoya, A., Ngueteu, A., Tchuindjang, Y.D. and Nkoumbou, C. (2017) Caractérisation chimique et minéralogique de quelques indices de bauxite de Foumban (Ouest-Cameroun). International Journal of Biological and Chemical Sciences, 11, 444-452. https://doi.org/10.4314/ijbcs.v11i1.35

[34] Tchamba, A.B., Melo, U.C., Lecomte-Nana, G.L., Kamseu, E., Gault, C., Yongue, R. and Njopwouo, D. (2014) Use of Bauxite from Cameroon for Solid State Sintering and Characterization of Calcium Dialuminate (CaO.2Al2O3) Refractory Cement. Ceramics International, 40, 1961-1970.

https://doi.org/10.1016/j.ceramint.2013.07.105

[35] Kloprogge, J.T., Ruan, H.D. and Frost, R.L. (2002) Thermal Decomposition of 
Bauxite Minerals: Infrared Emission Spectroscopy of Gibbsite, Boehmite and Diaspore. Journal of Materials Science, 37, 1121-1129. https://doi.org/10.1023/A:1014303119055

[36] Yusiharni, E. and Gilkes, R. (2012) Rehydration of Heated Gibbsite, Kaolinite and Goethite: An Assessment of Properties and Environmental Significance. Applied Clay Science, 64, 61-74. https://doi.org/10.1016/j.clay.2011.12.005

[37] Damigos, E. (2013) Déshydratation de la boehmite en alumine de transition. Étude thermodynamique et structurale. Génie des procédés. Thèse de l'Ecole Nationale Supérieure des Mines de Saint-Etienne, France.

[38] Karouia, F. (2014) Traitement thermique de boehmite de taille et forme de particules contrôlées: Vers l'optimisation des propriétés de l'alumine gamma. Thèse de doctorat, Université Toulouse 3, Paul Sabatier (UT3 Paul Sabatier), France.

[39] Ruan, H. (2005) Spectroscopic Studies of Nano-Structures of AI and Fe Phases, Bauxite and Their Thermally Activated Products. PhD by Publication, Queensland University of Technology, Brisbane.

[40] Pannirselvam, J., Tardio, G.A., Antolasic, F., Grocott, S. and Bhargava, S. (2010) Characterization of Bauxite Pisoliths. School of Applied Sciences, RMIT University, Melbourne, 5-7.

[41] De Souza Santos, H., Campos, T.W., De Souza Santos, P. and Kiyohara, P.K. (2005) Thermal Phase Sequences in Gibbsite/Kaolinite Clay: Electron Microscopy Studies. Ceramics International, 31, 1077-1084.

https://doi.org/10.1016/j.ceramint.2004.10.018

[42] Balde, M.Y., Djangang, N.C., Bah, A., Blanchart, P. and Njopwouo, D. (2020) Effect of Physicochemical Characteristics on the Use of Clays from Kindia (Guinea) in Ceramic Compositions. International Journal of Applied Ceramic Technology, 1-10. https://doi.org/10.1111/ijac.13669

[43] Mehta, P.K. (1973) Mechanism of Expansion Associated with Ettringite Formation. Cement and Concrete Research, 3, 1-6. https://doi.org/10.1016/0008-8846(73)90056-2

[44] ASTM C125-07 (2007) Standard Terminology Relating to Concrete and Concrete Aggregates.

[45] Ferraz, E., Andrejkovicova, S., Hajjaji, W., Velosa, A.N., Silva, A.S. and Rocha, F. (2015) Pozzolanic Activity of Metakaolins by the French Standard of the Modified Chapelle Test: A Direct Methodology. Acta Geodynamica et Geomaterialia, 12, 289-298. https://doi.org/10.13168/AGG.2015.0026 